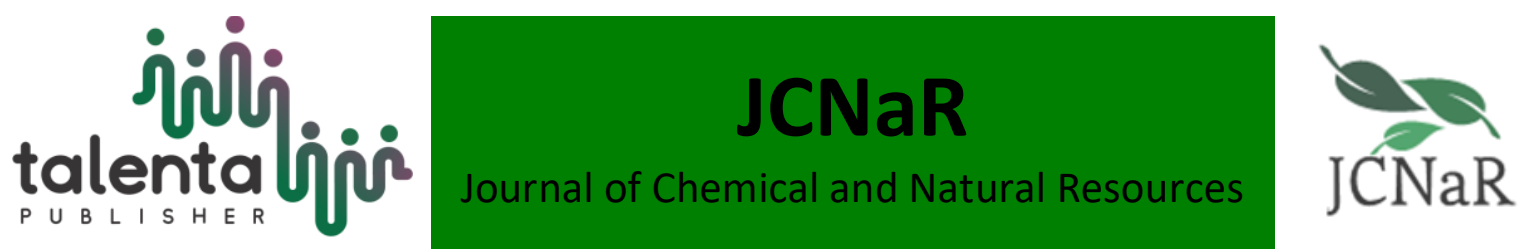

\section{Effect of Cadmium in Biosorption of Lead by Lengkeng Seed and Shell (Euphoria logan lour)}

\author{
Desy Kurniawati ${ }^{1 *}$, Intan Lestari ${ }^{3}$, Salmariza Sy ${ }^{3}$, Harmiwati ${ }^{5}$, \\ Hermansyah Aziz', Zulkarnain Chaidir' ${ }^{2}$ Rahmiana Zein ${ }^{2}$ \\ ${ }^{1}$ Department of Chemistry, Faculty of Mathematics and Natural Sciences, Universitas Negeri Padang, \\ Kampus Air Tawar, Jl. Prof. Dr. Hamka, West Sumatra, 25131, Indonesia \\ ${ }^{2}$ Laboratory of Analytical Environmental Chemistry, Department of Chemistry, Faculty of Mathematics \\ and Natural Sciences, Andalas University, Indonesia \\ ${ }^{3}$ Department of Chemistry, Faculty of Science and Technology, Jambi University, Indonesia \\ ${ }^{4}$ Institute for Research and Standardization of Industry Padang Indonesia \\ ${ }^{5}$ Department Chemical Engineering of Natural Product, Polytechnic ATI Padang, Indonesia
}

\begin{abstract}
In this study, the effect of of $\mathrm{Cd}$ (II) in biosorption of $\mathrm{Pb}$ (II) by lengkeng seed and sheel from a binary metal mixture was studied and compared with the single metal ion situation and other way. The purpose studied by the metal ion competition in the solution is to know the effect and the absorption capacity of one type of metal ion in a solution containing several metal ions inside which will be applied to the waste. The optimum conditions used were for $\mathrm{Pb}$ at $\mathrm{pH} 3$ and $\mathrm{Cd}$ at $\mathrm{pH} 5$ with a particle size of $250 \mu \mathrm{m}$. The results showed a decrease in the absorption of $\mathrm{Pb}$ metal ions reached $42.14 \%$ (for lengkeng sheel) and $57.07 \%$ (for lengkeng seed). And decrease of $\mathrm{Cd}$ metal ion to $68,11 \%$ for seed and $64,77 \%$ for lengkeng shell.
\end{abstract}

Keyword: Lengkeng Seed and Sheel, Biosorption, Cadmium, Lead, Competition.

Received 30 July 2019 | Revised 26 August 2019| Accepted 29 August 2019

\section{Introduction}

The existence of heavy metals in the environment due to industrial waste disposal containing chemicals can cause poisoning because it is toxic and dangerous if accumulated in the body, it is even possible to cause death. Heavy metal such as lead, cadmium and cobalt from the anthropogenic sources, metal plating, mining operations and other industries are among the most common pollutants found in industrial effluents, and become an environmental problem of worldwide concern. (Fourest, et.al , 1996, Kratochvil, 1998 ) (For this reason, before disposing it into the water, a set of process is required to be performed first. Some techniques

\footnotetext{
*Corresponding author at: Department of Chemistry, Faculty of Mathematics and Natural Sciences, Universitas Negeri Padang, Kampus Air Tawar, Jl. Prof. Dr. Hamka, West Sumatra, 25131, Indonesia.

E-mail address: desy.chem@gmail.com
} 
that have been used to absorb heavy metals are ion exchange, precipitation, coagulation, membrane separation and adsorption (Kurniawati et al, 2015, Adeloja et al , 2011, Jimoh, et al 2013).

This method is highly expensive and ineffective because it requires huge cost in the waste treatment process. The most commonly used biosorption is the activated carbon and ion exchange resins which have high prices, therefore in this study the alternative biosorbents that are easily obtained and cheap to absorb metal ions that are used. Some researches that have been done to absorb heavy metals are the skin of the mangosteen fruit (Zein, R., et.al, 2010), durian seeds (Lestari, I., et.al, 2016), langsat fruit seeds (Wahyuni, D., et al, 2014), apple skin (Sureshet.al, 2014), melon seeds (Adelagun, et.al, 2014), soursop seeds (Kurniawan et al, 2014), tomatoes (Yargic et al, 2015), seeds longan skin (Kurniawati et al, 2015), banana, lemon and orange cortex ( Kevin et al, 2012), peanut shell (Seyda, et al, 2014), tomato waste (As, et al, 2015), papaya seed (Norhafizah, 2011) to name a few. Besides, the advantage of this biosorbent is it can be regenerated and reused (Xi et al, 2013, Gupta, et al , 2009, Wang, 2009).

The previous research has shown that longan skin seeds can absorb $\mathrm{Pb}$ (II) metal with the absorption capacity of $4.8933 \mathrm{mg} / \mathrm{g}$ for skin and $5.2720 \mathrm{mg} / \mathrm{g}$ for seeds (Kurniawati et al, 2015). In industrial waste, it usually contains several kinds of metals produced in the processing process and therefore it is necessary to study the effect of the existence of other metals that affect the process of absorption of $\mathrm{Pb}$ (II) metal ions using longan seeds and skin as biosorbent (binary metal competition) and vice versa. The aim of studying the competition of metal ions in solution is to determine the effect and absorption capacity of one type of metal ion in a solution containing several metal ions in it which will later be applied to the waste.

\section{Materials and Methods}

\subsection{Sample Preparation}

The sample used as the adsorbent for $\mathrm{Cd}$ and $\mathrm{Pb}$ metals adsorption in liquid. The seeds and the skins of the fruits are washed with the deionized water, wind-dried. The dried sample is whisked with $250 \mu \mathrm{m}$ size. Then as much as 20 gram of longan seeds/ skin is activated by being soaked in $80 \mathrm{~mL}$ of $\mathrm{HNO} 30.01 \mathrm{M}$ for 2 hours and neutralized with aquades, then wind-dried (Kurniawati et al, 2015).

\subsection{The materials used}

The longan skin and seeds obtained from the Padang market, silver nitrate crystals $\left(\mathrm{Pb}\left(\mathrm{NO}_{3}\right)_{2}\right)$, Metal Cd, nitric acid $\left(\mathrm{HNO}_{3} 65 \%\right), \mathrm{NaOH}, \mathrm{NH}_{4} \mathrm{OH}$.

\subsection{The Effect of the Competition of $\mathrm{Pb}(\mathrm{II})$ and $\mathrm{Cd}(\mathrm{II})$ Ions}


0.5 gram of biomass is inserted into the column, added $10 \mathrm{ml}$ of a solution of $\mathrm{Pb}$ (II) and $\mathrm{Cd}$ (II) ions with various concentrations:

a. The concentration of $\mathrm{Pb}$ (II) $200 \mathrm{mg} / \mathrm{L}$ and the concentration of $\mathrm{Cd}(\mathrm{II})$ were varied between $50,100,150$ and $200 \mathrm{mg} / \mathrm{L}$. In binary solutions this is carried out under optimum conditions for absorption of $\mathrm{Pb}$ (II) metal. After the absorption using longan seeds and skin as biosorbent is done, then the filtrate is collected and analyzed for absorption of $\mathrm{Pb}(\mathrm{II})$ ions using AAS.

b. The $\mathrm{Cd}(\mathrm{II}) 200 \mathrm{mg} / \mathrm{L}$ concentration and $\mathrm{Pb}$ (II) concentration varied between 50, 100, and $150 \mathrm{mg} / \mathrm{L}$. In binary solutions this is carried out under optimum conditions for metal absorption $\mathrm{Cd}(\mathrm{II})$. After the absorption using seeds and longan skin as biosorbent, then the filtrate is collected and analyzed for absorption of Cd(II) ions using AAS.

\section{Results And Discussion}

\subsection{The Mixture of the Metal Ions $\mathrm{Cd}(\mathrm{II})$ and $\mathrm{Pb}(\mathrm{II})$}

The competition between metal ions $\mathrm{Cd}(\mathrm{II})$ and $\mathrm{Pb}$ (II) on the skin and seeds of longan fruit was studied using a solution containing $\mathrm{Cd}$ (II) and $\mathrm{Pb}$ (II) ions, then each of the metal ions was measured for their absorption capacity and for the effect of ion addition other metals to biosorbent absorption capacity. The results of the study are shown in Figure 1, that the maximum absorption capacity of single $\mathrm{Pb}$ (II) ions is $5.5450 \mathrm{mg} / \mathrm{g}$, when $\mathrm{Pb}$ (II) ions are mixed with $\mathrm{Cd}(\mathrm{II})$ ions with variations in concentrations of 50,100, 150 and $200 \mathrm{mg} / \mathrm{L}$, the result obtained was the ion absorption capacity of $\mathrm{Pb}$ (II) was $3.5303 ; 3.4772 ; 2,3807$; and $3.4099 \mathrm{mg} /$ g. So the existence of metal ions $\mathrm{Cd}$ (II) in solution can cause a decrease in the absorption capacity of $\mathrm{Pb}$ (II) ions in longan fruit seeds, but the addition of $\mathrm{Cd}$ (II) ion concentrations in the solution does not give a significant difference in the absorption capacity of $\mathrm{Pb}(\mathrm{II})$ ions. This is because $\mathrm{Pb}(\mathrm{II})$ and $\mathrm{Cd}(\mathrm{II})$ ions are absorbed on the active side that are different from biosorbent.
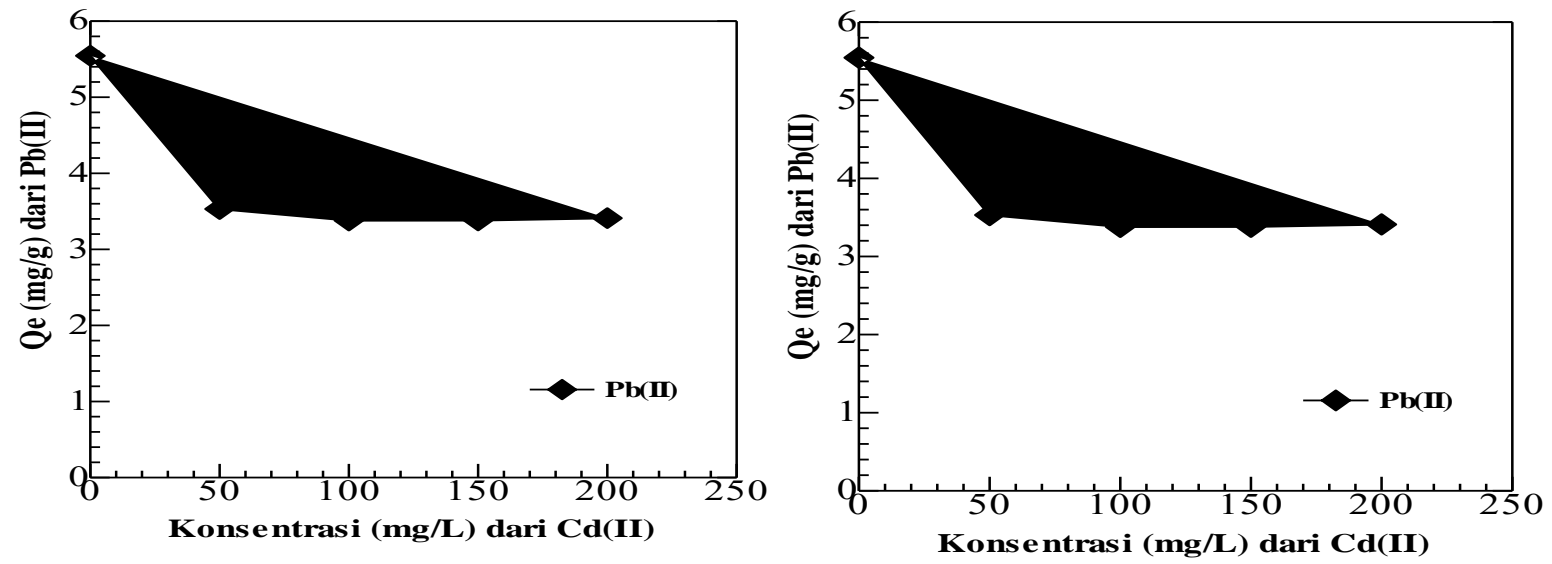

Figure 1. The Effect of metal ion $\mathrm{Pb}(\mathrm{II})$ with the existence of $\mathrm{Cd}(\mathrm{II})$ in longan seeds; the concentrations of $\mathrm{Pb}(\mathrm{II}) 200 \mathrm{mg} / \mathrm{L}, \mathrm{Cd}(\mathrm{II})=50,100,150,200 \mathrm{mg} / \mathrm{L}$

The similar matter can also be seen in Figure 2, where the absorption capacity of metal ion $\mathrm{Pb}$ (II) on longan skin experienced decrement after the presence of $\mathrm{Cd}(\mathrm{II})$ ions in the solution, 
which was $5.5850 \mathrm{mg} / \mathrm{g}$ to $3.489 ; 3.3792 ; 3.2684$ and $3.2316 \mathrm{mg} / \mathrm{g}$, but the difference in absorption capacity of $\mathrm{Pb}(\mathrm{II})$ ions was not significant with the increase in the concentration of $\mathrm{Cd}$ (II) ions added to the solution. So the addition of $\mathrm{Cd}(\mathrm{II})$ ions to the solution does not affect the absorption capacity of $\mathrm{Pb}$ (II) by skin or $\mathrm{Cd}$ (II) which is added to non-competitive $\mathrm{Pb}$ (II) to bind the active side. This is in accordance with the study of Mahamadi and Nharingo (2010) who studied the competitive adsorption of $\mathrm{Pb}$ (II), $\mathrm{Cd}$ (II) ions in water hyacinth in a binary and ternary system.

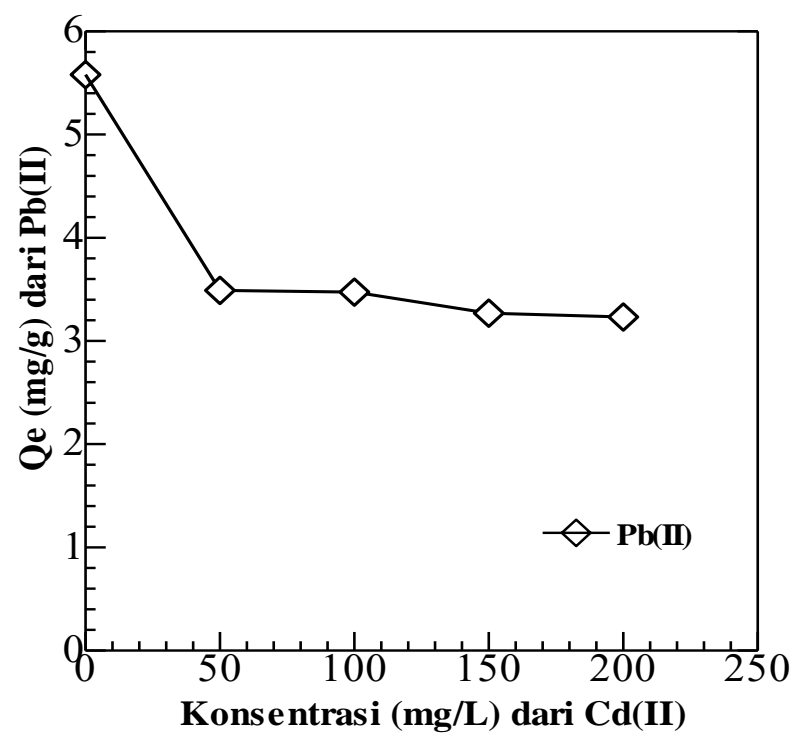

Figure 2. The Effect of metal ion $\mathrm{Pb}(\mathrm{II})$ with the existence of $\mathrm{Cd}(\mathrm{II})$ in the longan skin; $\mathrm{Pb}$ (II) concentration of $200 \mathrm{mg} / \mathrm{L}, \mathrm{Cd}(\mathrm{II})=50,100,150,200 \mathrm{mg} / \mathrm{L}$.

\subsection{The Mixture of Metal Ion $\mathrm{Pb}(\mathrm{II})$ and $\mathrm{Cd}(\mathrm{II})$}

The effect of the mixture of metal ion $\mathrm{Pb}$ (II) and $\mathrm{Cd}(\mathrm{II})$ on the absorbent capacity by the longan seeds. From the figure, it is known that the absorbent capacity of the metal ion $\mathrm{Cd}(\mathrm{II})$ before the addition of the metal ion $\mathrm{Pb}$ (II) in the solution which is $3.2900 \mathrm{mg} / \mathrm{g}$. Then it experienced a decrease by the addition of the metal ion $\mathrm{Pb}$ (II) in the solution with the variation of concentration of 50, 100 and $150 \mathrm{mg} / \mathrm{L}$ with the absorbent capacity of 2.931; 2.771; and 1.049 $\mathrm{mg} / \mathrm{g}$, however there is an increment of the absorbent in the addition of $\mathrm{Pb}$ (II) ion with the concentration of $200 \mathrm{mg} / \mathrm{L}$ to become $2.307 \mathrm{mg} / \mathrm{g}$. 


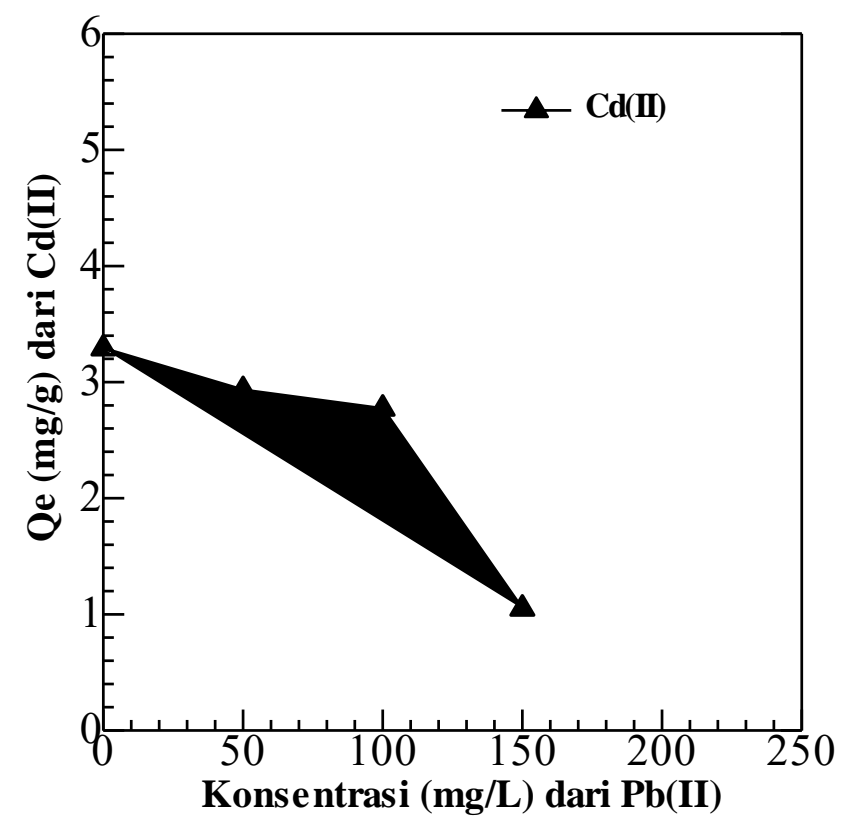

Figure 3. The Effect of the metal ion $\mathrm{Cd}(\mathrm{II})$ with the existence of $\mathrm{Pb}(\mathrm{II})$ in longan seeds; the concentration of $\mathrm{Cd}(\mathrm{II}) 200 \mathrm{mg} / \mathrm{L}, \mathrm{Pb}(\mathrm{II})=50,100,150,200 \mathrm{mg} / \mathrm{L}$

The same condition is also shown in Figure 4 that the mixture of the metal ion $\mathrm{Cd}(\mathrm{II})$ and $\mathrm{Pb}$ (II) in the solution affects the absorbent capacity by longan skin, then it can be said that the occurrence of the competition of the metal ion $\mathrm{Cd}(\mathrm{II})$ and $\mathrm{Pb}$ (II) in the binding of the active side in the biosorbent of longan skin and seeds. According to $\mathrm{Yu}$ et al (2013), $\mathrm{Pb}$ (II) ion is the metal that atom mass of more than (207.2), paramagnetic, is the ion with excessive electronegative $(\mathrm{Pb} 2+(2.33)>\mathrm{Cd} 2+(1.69))$ and has the smaller ion radius of $(\mathrm{Pb} 2+(0.401 \mathrm{~nm})>\mathrm{Cd} 2+(0.426$ $\mathrm{nm})$ ), based on those characteristics, then $\mathrm{Pb}(\mathrm{II})$ ion is absorbed more in the carboxylic functional group of longan skin and seeds.

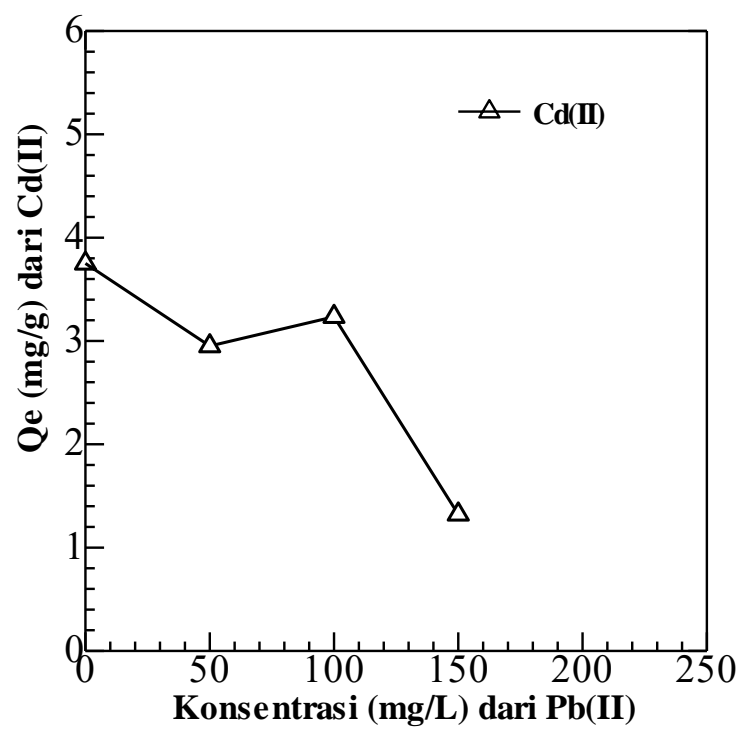

Figure 4. The effect of the metal ion $\mathrm{Cd}(\mathrm{II})$ with the existence of $\mathrm{Pb}(\mathrm{II})$ in longan skin; concentration of $\mathrm{Cd}(\mathrm{II}) 200 \mathrm{mg} / \mathrm{L}, \mathrm{Pb}(\mathrm{II})=50,100,150,200 \mathrm{mg} / \mathrm{L}$. 
In the picture above, it is displayed that the absorbent capacity on the metal ion $\mathrm{Cd}$ (II) in longan skin before the addition of metal ion $\mathrm{Pb}$ (II) in the solution that is $3.750 \mathrm{mg} / \mathrm{g}$. Then it experienced decrement with the addition of the metal ion $\mathrm{Pb}(\mathrm{II})$ in the solution with the variation of concentration of 50,100 and $150 \mathrm{mg} / \mathrm{L}$ with the absorbent capacity of 2.9505 ; 3.2345 ; and $1.321 \mathrm{mg} / \mathrm{g}$, however there is increment of the absorbent on the addition of $\mathrm{Pb}$ (II) ion with the concentration of $200 \mathrm{mg} / \mathrm{L}$ to become $2.8735 \mathrm{mg} / \mathrm{g}$.

\section{Conclusion}

The binary combination of $\mathrm{Pb}(\mathrm{II})$ and $\mathrm{Cd}(\mathrm{II})$ in the absorbent using longan skin and seeds as the biosorbent highly affecting the absorption process. This condition is the result of the effect of the active side of the biosorbent to bind each different metal ion and the occurrence of the competition between the metal ion $\mathrm{Pb}(\mathrm{II})$ and $\mathrm{Cd}(\mathrm{II})$ in the absorption process. It is recommended to conduct the absorption of the metal ions in three, four or even more mixture of metal ions.

\section{References}

[1] Adelagun, R.O.A,A.U. Itodo, E.P. Berezi, O.J. Oko, E.A. Kamba, C. Andrew, H.A. Bello. 2014. Adsorption of $\mathrm{Pb} 2+$ from aqueous solution by modified melon(Citrullus lanatus) seed husk. Chemistry and Materials Research. 6(2)

[2] Adeloja O, Amoo I. A., AD A. 2011. Archieves of Applied Science Research 3:50-60

[3] AS Yargic, RZ Yarbay Sahin N, Onal OE. 2015. Journal of Cleaner Production 152-9

[4] Fourest, E., Volesky B.,1996, Contribution of sulfonate groups and alginate to heavy metal biosorption by the dry biomass of Sargassum fluitants (J), Environ. Sci. Technol. 30 (1) . pp. 277-282.

[5] Gupta VK, Suhas. 2009. Application of low-cost adsorbents for dye removal - a review. J Environ Manage ;90:2313-42

[6] Jimoh Oladejo Tijani, Muhammed Muhammed Ndamitso, Ibrahim Bukola Aliyu, Olakunle OS. 2013. International Journal of Advancements in Research and Technology 2:1-29

[7] Kevin Kelly Vargaj, Monica Cerro-Lopez, Silvia Reyna-Tellez, Erick R., Bandala, Sanchez-Sales JL. 2012. Physics and Chemistry of The Earth:26-9

[8] Kratochvil , D. , Volesky, B., 1998, Advances the biosorption of heavy metals, Trends Biotechnol. 16 (7) pp. 291-300.

[9] Kurniawan, M.I, Z. Abdullah, A. Rahmadani, R. Zein, and E. Munaf., 2014. Isotherm and Kinetic Modeling of $\mathrm{Pb}(\mathrm{II})$ and $\mathrm{Cu}(\mathrm{II})$ Uptake by Annona muricata L. Seeds. Asian Journal of Chemistry. 26(12): 3588-3594

[10] Kurniawati, D., I. Lestari, Harmiwati, R. Zein et.al. 2015. Biosorption of $\mathrm{Pb}$ (II) from aqueous solutions using column method by lengkeng (Euphoria logan lour) seed and shell. Journal of Chemical and Pharmaceutical Research.7(12); 872-877 
[11] Lestari, I., S. Sy, Harmiwati, D. Kurniawati4, A. Alif, R. Zein and H. Aziz. 2016. Effect of $\mathrm{pH}$ on the biosorption of heavy metal by alginate immobilized durian(Durio zibethinus) seed. Der Pharma Chemica. 8(5):294-300

[12] Mahamadi, C., T. Nharingo. 2010. Competitive adsorption of $\mathrm{Pb} 2+, \mathrm{Cd} 2+$ and $\mathrm{Zn} 2+$ ions onto Eichhornia crassipes in binary and ternary systems, Bioresource Technology. 101: 859-864

[13] Norhafizah binti Abd Hadi, Nurul Aimi binti Rohaizar, Sien WC. 2011. Asian Transsactions on Engineering 1:49-55

[14] Seyda Tasar, Fatih Kaya, Ozer A. 2014. Journal of Environmental Chemical Engineering $1018-26$

[15] Suresh, Ch., D.H.K. Reddy, Y. Harinath, B.R. Naik, K. Seshaiah, and A.V.R. Reddy.2014. Development of Wood Apple Shell (Feronia acidissima) Powder Biosorbent and Its Application for the Removal of Cd(II) from Aqueous Solution.

[16] Wahyuni, D., F. Furqani, A. W. Astuti, Khoiriah, Indrawati, R. Zein, andE. Munaf. 2014. Removal of Cadmium (II) and Copper (II) from Aqueous Solution by UsingLangsat Fruit (Lansium domesticum Corr) Seed.Research Journal of Pharmaceutical Biological and ChemicalScience. 5(5), 1320-1328

[17] Wang XS, Chen JP. 2009. Biosorption of Congo Red from aqueous solution using wheat bran and rice bran: batch studies. Separ Sci Technol ;44:1452-66

[18] Xi, Y., Shen, Y., Yang, F., Yang, G., Liu, C., Zhang, Z., Zhu, D., 2013. Removal of azo dye from aqueous solution by a new biosorbent prepared with Aspergillus nidulans cultured in tobacco wastewater. Journal Taiwan Institute Chemical Engineers. 44, 815820

[19] Yargic, A.S. R.Z. Yarbay S, ahin, N. Ozbay, E. Onal. 2015. Assessment of toxic copper (II) from aqueous solution by chemically-treated tomato waste. Journal of cleaner production $86 ; 152-159$.

[20] Yu, J.X., L. Y. Wang, R. A. Chi, Y. F. Zhang, Z. G. Xu, J. Guo. 2013. Competitive adsorption of $\mathrm{Pb} 2+$ and $\mathrm{Cd} 2+$ on magnetic modified sugarcane bagasse prepared by two simple steps. Applied Surface Science. 268: 163-170

[21] Zein, R., R. Suhaili, F. Earnestly. 2010. Removal of $\mathrm{Pb}(\mathrm{II}), \mathrm{Cd}(\mathrm{II})$ and $\mathrm{Co}(\mathrm{II})$ from aqueous solution using Garcinia mangostana L,fruit shell. Journal of Hazardous materials.181; 52-56. 